CZASOPISMO INŻYNIERII LA¿DOWEJ, ŚRODOWISKA I ARCHITEKTURY JOURNAL OF CIVIL ENGINEERING, ENVIRONMENT AND ARCHITECTURE JCEEA, t. XXXIII, z. 63 (2/II/16), kwiecień-czerwiec 2016, s. 39-52

\author{
Dorian CZARNIECKI ${ }^{1}$ \\ Daniel SŁY Ś
}

\title{
ANALIZA TECHNICZNA I FINANSOWA PODGRZEWANIA MURAWY BOISKA SPORTOWEGO
}

\begin{abstract}
W ostatnich latach w Polsce nadrobione zostały wieloletnie zaległości w budowie infrastruktury sportowej, dedykowanej w głównej mierze dzieciom i młodzieży oraz zapewnieniu społeczeństwu szerokiego i bezpłatnego dostępu do nowoczesnych obiektów sportowych. Niezbędna staje się potrzeba poszukiwania nowych rozwiązań, których zastosowanie przyczyni się do znacznej poprawy warunków uprawiania sportu w kraju. Należy przy tym dać pierwszeństwo wszystkim proekologicznym systemom przyczyniającym się do racjonalizacji wykorzystania energii, a dzięki temu również do ochrony powietrza atmosferycznego. Odpowiedzią na taki trend jest ogrzewanie boisk i muraw stadionów przy użyciu pompy ciepła. $\mathrm{W}$ artykule przedstawiono wyniki analizy technicznej ogrzewania płaszczyznowego płyty boiska przy użyciu tego urządzenia, jak również analizy finansowej jego zastosowania w ustalonych uwarunkowaniach. Znajomość tych analiz daje możliwość wyboru najkorzystniejszego wariantu systemu dla obecnej i nowobudowanej infrastruktury sportowej, co w znacznym stopniu może przyczynić się do zmniejszenia kosztów eksploatacyjnych.
\end{abstract}

Słowa kluczowe: boisko sportowe, ogrzewanie płaszczyznowe, pompa ciepła, odnawialne źródła energii

\section{Wprowadzenie}

Obserwowany w ostatnich latach znaczący wzrost zainteresowania nowoczesnymi systemami ogrzewania, których innowacyjność często dyktowana jest Względami ekonomiczno-ekologicznymi, sprawia, że nasz kraj może się pochwalić infrastrukturą sportową na światowym poziomie. W ciągu dekady

\footnotetext{
${ }^{1}$ Autor do korespondencji / corresponding author: Dorian Czarniecki, Politechnika Rzeszowska, Wydział Budownictwa, Inżynierii Środowiska i Architektury, Zakład Infrastruktury i Ekorozwoju, al. Powstańców Warszawy 6, 35-959 Rzeszów, tel. +48 17 7432409, e-mail: doriancz@prz.edu.pl

2 Daniel Słyś, Politechnika Rzeszowska, Wydział Budownictwa, Inżynierii Środowiska i Architektury, Zakład Infrastruktury i Ekorozwoju, al. Powstańców Warszawy 6, 35-959 Rzeszów, tel. +48 17 8651784, e-mail: daniels@ @rz.edu.pl
} 
w Polsce przybyło obiektów spełniających dość rygorystyczne wymagania FIFA i UEFA, a co cieszy jeszcze bardziej, ogólnodostępnych boisk sportowych wybudowanych w ramach programu „Moje Boisko - Orlik 2012”.

Mecze piłkarskie są rozgrywane na tych większych obiektach do późnej jesieni, gdy możliwe są opady śniegu oraz pierwsze przymrozki, z kolei kapryśna aura może również sprawiać niespodzianki w trakcie kalendarzowej wiosny. Natomiast Orliki w większości przypadków umożliwiają grę w piłkę przez cały rok, nawet w okresie zimowym. W celu zapewnienia bezpieczeństwa piłkarzy, jak również umożliwienia rozgrywania meczów w tych okresach, niezbędna staje się potrzeba zastosowania ogrzewania i odpowiedniego drenażu murawy [12].

Niskotemperaturowe systemy grzewcze są powszechnie stosowane w ogrzewaniu płaszczyznowym typu podłogowego, sufitowego czy ściennego, mogą one być również stosowane do ogrzewania powierzchni otwartych. Bez wątpienia mogą być wykorzystane do podgrzewania boisk i muraw stadionów, ogrzewania dróg i ciągów komunikacyjnych, schodów, podjazdów czy tarasów, stykających się z powietrzem zewnętrznym. W tym pierwszym przypadku, wykonanie instalacji ogrzewania płaszczyznowego jest bardziej skomplikowane niż w przypadku budynków, głównie z uwagi na trawę, która wymaga odpowiedniej temperatury dla prawidłowej wegetacji, aby nie ulegała zniszczeniu [8].

System ogrzewania płyty boiska sportowego spełnia następujące funkcje:

- zapobieganie powstawaniu warstwy lodu na powierzchni boiska,

- umożliwianie utrzymywania założonej temperatury na jej płycie,

- zachowanie sprężystości sztucznej murawy,

- ułatwienie rozmrażania powstałego lodu i śniegu,

- zapewnienie suchej i czystej nawierzchni.

Ogrzewanie powierzchni otwartych, mających kontakt z powietrzem zewnętrznym, realizowane jest przez montaż rur typu PEX w podłożu bezpośrednio pod powierzchnią. Aby nie dopuścić do zamarznięcia instalacji, nawet przy nieużytkowaniu systemu w okresie zimowym, jako czynnik grzejny stosowany jest wodny roztwór glikolu [8].

$\mathrm{W}$ tradycyjnych instalacjach podgrzewanie płyty boiska realizowane jest w większości przypadków za pomocą specjalistycznych elektrycznych kabli grzejnych i mat, przy użyciu węzłów cieplnych, jak również z lokalnych kotłowni opalanych paliwem gazowym lub płynnym. $Z$ uwagi na to, że systemy te nie wymagają wysokiej temperatury roboczej, występuje możliwość stosowania do ich zasilania alternatywnych źródeł energii, tj. pomp ciepła, instalacji słonecznych, itp. Mając na uwadze znaczne nakłady inwestycyjne na instalacje tego typu, istotne jest dokonanie analizy finansowej takiej inwestycji. Ze względu na zastosowany czynnik grzejny instalacja łączona jest ze źródłem ciepła za pomocą wymiennika ciepła. 
Płyta boiska powinna być również zaopatrzona w odpowiedni drenaż umożliwiający odprowadzanie wód opadowych oraz wód powstałych po roztopieniu śniegu i lodu. Dodatkowym elementem jest system nawadniający trawę w sezonie wiosennym i letnim $[11,14]$.

Obecnie obserwuje się wzrost zainteresowania systemami ogrzewania powierzchni otwartych, zwłaszcza systemami do ogrzewania muraw boisk sportowych. Pojawia się więc konieczność dokładnego przeanalizowania celowości zastosowania pompy ciepła jako alternatywnego źródła energii.

\section{Projektowanie systemu podgrzewania płyty boiska sportowego z wykorzystaniem pompy ciepła}

Systemy podgrzewania płyty boiska umożliwiają roztopienie warstwy śniegu zalegającej na powierzchni, jednakże w praktyce nie ma to większego sensu. Celowe jest $\mathrm{w}$ takim przypadku wcześniejsze usunięcie zalegającego na powierzchni śniegu, a następnie uruchomienie instalacji. Zadaniem funkcji grzewczej jest przyczynienie się do roztopienia tego, co pozostało na powierzchni, i nie dopuszczenie do powstawania bryłek lodu. W związku z powyższym projektowanie systemu podgrzewania murawy boiska sportowego opiera się na założeniu, że temperatura płyty grzewczej mieści się w granicach od $+1 \mathrm{do}+5^{\circ} \mathrm{C}$ [8]. Działanie całego systemu wspierane jest przez czujniki śniegu, oblodzenia i temperatury, które współpracują z cyfrowymi regulatorami.

Wymiennik poziomy ma postać równoległych pętli o równej długości najczęściej z jednym nawrotem, pojedynczym zasilaniem i powrotem. Dzięki temu zapewniony zostaje jednakowy przepływ przez poszczególne pętle oraz równomierny rozkład temperatury $\mathrm{w}$ całej ogrzewanej powierzchni. Wykonane z sieciowanego polietylenu pętle grzewcze instaluje się na głębokości $25-30 \mathrm{~cm}$ w warstwie pospółki - w zależności od indywidualnych uwarunkowań klimatyczno-gruntowych [9]. Kolektory z króćcami przyłączeniowymi wykonane $\mathrm{z}$ rur polietylenowych (PE-RT) układane są standardowo wzdłuż dłuższego boku boiska w układzie Tichelmanna. ku 1.

Schemat przekroju przez płytę boiska piłkarskiego przedstawiono na rysun-

Zaproponowano system ogrzewania płaszczyznowego płyty boiska sportowego z wykorzystaniem pompy ciepła (rys. 2). Jako źródło dolne może być wykorzystany grunt, woda, powietrze, ciepło odpadowe, itp. [13].

$\mathrm{W}$ analizowanym przykładzie podgrzewanie murawy następuje przy użyciu jednostopniowej pompy ciepła pracującej w układzie ciecz-ciecz, współpracującej $\mathrm{z}$ układem przewodów cieczowych rozmieszczonych pod płytą boiska. Czynnikiem grzewczym jest woda o temperaturze $17^{\circ} \mathrm{C}$, która odpływa ze skraplacza pompy ciepła, przepływa przez przeciwprądowy wymiennik ciepła, gdzie oddaje zdeponowane $\mathrm{w}$ niej ciepło ochładzając się do temperatury $13^{\circ} \mathrm{C}$ 
i ponownie jest wtłaczana do skraplacza. Jednocześnie następuje podgrzanie krążącego w obiegu zamkniętym wodnego roztworu glikolu etylenowego z $11^{\circ} \mathrm{C}$ do $16^{\circ} \mathrm{C}$. Dolnym źródłem dla pompy ciepła jest woda, która stanowi korzystne źródło niskotemperaturowe, z uwagi na jej dużą pojemność cieplną [4]. W zimie woda jest tłoczona przez pompę głębinową do parownika pompy ciepła. Po przejściu przez parownik woda ochładza się z temperatury $6^{\circ} \mathrm{C}$ do $2^{\circ} \mathrm{C}$, a następnie jest wtłaczana ponownie do zbiornika wodnego. W parowniku czynnik chłodniczy odbiera ciepło od wody. Gorący czynnik chłodniczy skrapla się w skraplaczu i oddaje ciepło do wodnej instalacji grzewczej. W okresie letnim zaproponowano wyłączenie instalacji pompy ciepła.
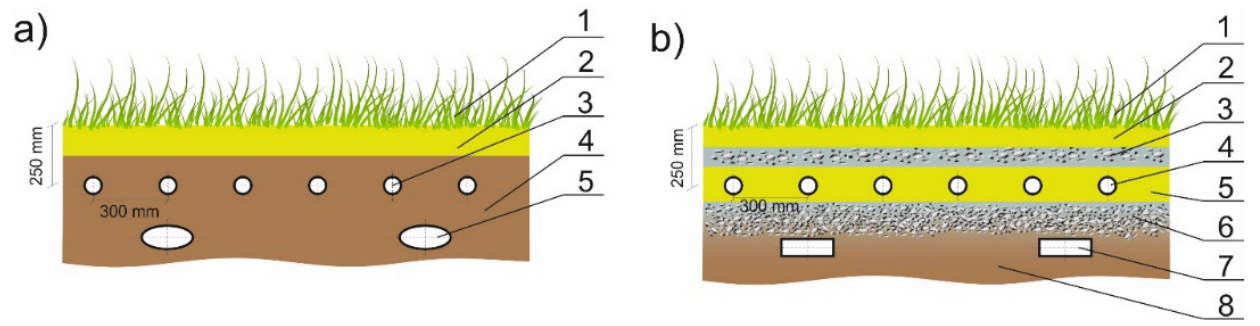

Rys. 1. Schematyczny przekrój płyty boiska sportowego: a) nawierzchnia naturalna: 1 - murawa, 2 - podkład wymienny (piasek), 3 - rury grzewcze, 4 - grunt rodzimy, 5 - drenaż; b) nawierzchnia sztuczna: 1 sztuczna murawa, 2 - podsypka (np. piasek i zmielona guma), 3 - żwir, 4 - rury grzewcze, 5 - piasek, 6 - żwir, 7 - drenaż, 8 grunt rodzimy (na podstawie [12])

Fig. 1. Schematic cross-section through board sports field: a) natural surface: 1 - turf, 2 - primer removable (sand), 3 - heating pipes, 4 - subsoil, 5 - drainage; b) artificial surface: 1 - artificial turf, 2 - ballast (eg. sand and crumb rubber), 3 - gravel, 4 - heating pipes, 5 - sand, 6 - gravel, 7 - drainage, 8 - subsoil (based on the [12])

Instalacja dolnego źródła ciepła składa się z pompy głębinowej tłoczącej wodę do parownika, zaworów odcinających usytuowanych na zasilaniu i powrocie instalacji oraz filtra eliminującego zanieczyszczenia umieszczonego na zasilaniu instalacji [10].

Instalacja grzewcza składa się z pomp obiegowych wymuszających przepływ czynników grzewczych (woda, wodny roztwór glikolu etylenowego), zaworów zwrotnych chroniących pompy przed niepożądaną zmianą kierunku przepływu obu mediów, filtrów eliminujących zanieczyszczenia, naczyń wzbiorczych i zaworów bezpieczeństwa chroniących instalację przed nadmiernym ciśnieniem oraz przeciwprądowego płytowego wymiennika ciepła [10].

$\mathrm{Na}$ rysunku 2 przedstawiono schemat analizowanego systemu podgrzewania murawy boiska sportowego przy użyciu pompy ciepła. 


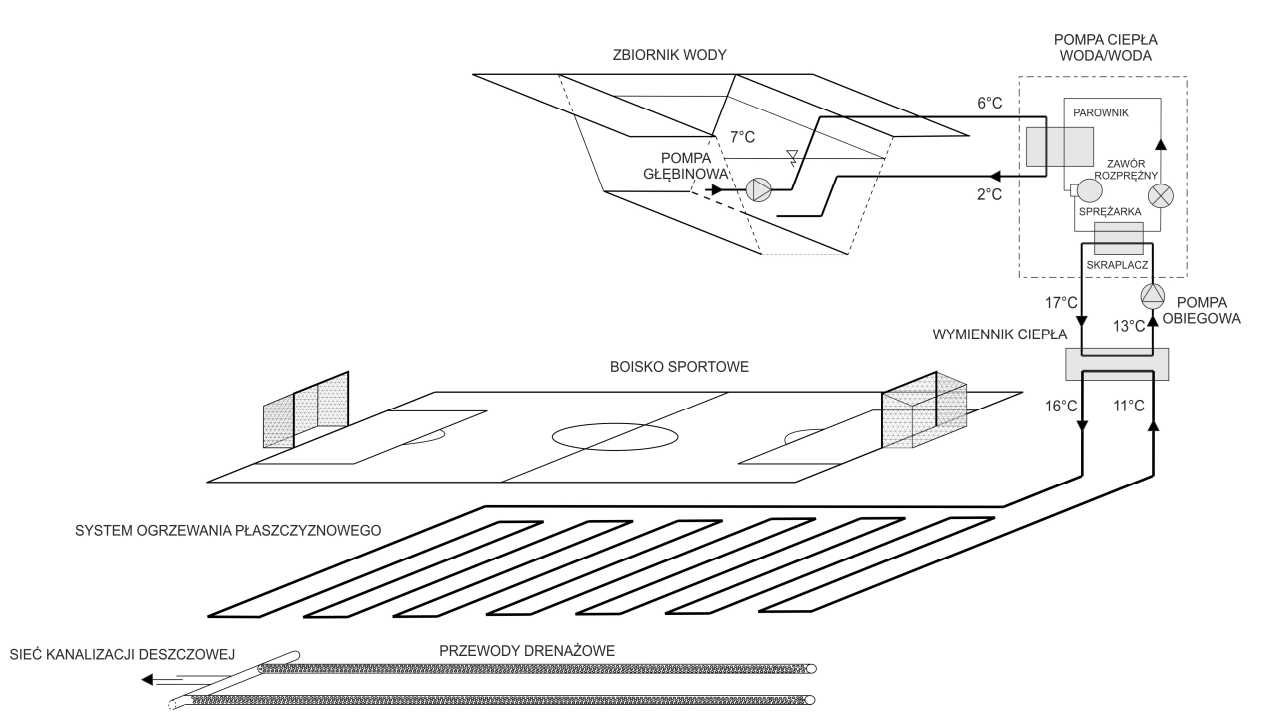

Rys. 2. Schemat systemu ogrzewania murawy boiska sportowego przy użyciu pompy ciepła

Fig. 2. Diagram of the hydronic turf heating system using a heat pump

Współczynnik przenikania ciepła $U_{b}$ od pętli grzewczych do otoczenia obliczono dla nawierzchni naturalnej ze wzoru (1).

$$
U_{b}=\frac{1}{\frac{h_{p}}{\lambda_{p}}+\frac{h_{g}}{\lambda_{g}}+\frac{1}{\alpha_{p}}}, \frac{W}{m^{2} \cdot K}
$$

gdzie: $h_{p}$ - grubość warstwy podkładu wymiennego, m;

$\lambda_{p}$ - współczynnik przewodzenia ciepła warstwy podkładu wymiennego, $\mathrm{W} /(\mathrm{m} \cdot \mathrm{K})$;

$h_{g}$ - grubość warstwy gruntu rodzimego, m;

$\lambda_{g}$ - współczynnik przewodzenia ciepła warstwy gruntu rodzimego, $\mathrm{W} /(\mathrm{m} \cdot \mathrm{K})$;

$\alpha_{p}$ - współczynnik wnikania ciepła z nawierzchni boiska do otoczenia, $\mathrm{W} /(\mathrm{m} \cdot \mathrm{K})$.

Z kolei dla nawierzchni sztucznej wartość współczynnika przenikania ciepła $U_{b}$ można obliczyć z zależności (2).

$$
U_{b}=\frac{1}{\frac{h_{p w}}{\lambda_{p w}}+\frac{h_{i w}}{\lambda_{z w}}+\frac{h_{p}}{\lambda_{p}}+\frac{1}{\alpha_{p}}}, \frac{W}{m^{2} \cdot K}
$$

gdzie: $h_{p w}$ - grubość warstwy podkładu wymiennego, m;

$\lambda_{p w}$ - współczynnik przewodzenia ciepła warstwy podkładu wymiennego, $\mathrm{W} /(\mathrm{m} \cdot \mathrm{K})$;

$h_{z w}$ - grubość warstwy żwiru, m; 
$\lambda_{z w}-$ współczynnik przewodzenia ciepła warstwy żwiru, $\mathrm{W} /(\mathrm{m} \cdot \mathrm{K})$;

$h_{p}$ - grubość warstwy piasku, m;

$\lambda_{p}$ - współczynnik przewodzenia ciepła warstwy piasku, $\mathrm{W} /(\mathrm{m} \cdot \mathrm{K})$;

$\alpha_{p}$ - współczynnik wnikania ciepła $\mathrm{z}$ nawierzchni boiska do otoczenia, $\mathrm{W} /(\mathrm{m} \cdot \mathrm{K})$.

Strumień ciepła $Q$ doprowadzony do pętli grzewczych obliczono na podstawie wzoru (3) [10].

$$
Q=U_{b} \cdot A \cdot\left(T_{g}-T_{w}\right), W
$$

gdzie: $A$ - powierzchnia płyty boiska sportowego, $\mathrm{m}^{2}$;

$T_{g}$ - temperatura pętli grzewczych, ${ }^{\circ} \mathrm{C}$;

$T_{w}$ - temperatura powietrza zewnętrznego, ${ }^{\circ} \mathrm{C}$.

Strumień przepływu wody grzewczej $V_{g}$ kierowanej do wymiennika ciepła oblicza się dla okresu zimowego, przyjmując temperaturę początkową wody $T_{p}$ i temperaturę końcową wody $T_{k}$. Korzysta się ze wzoru (4) [10].

$$
V_{g}=\frac{Q}{\rho_{w} \cdot c_{w} \cdot\left(T_{p}-T_{k}\right)}, \frac{m^{3}}{s}
$$

gdzie: $\rho_{w}$ - gęstość wody, $\mathrm{kg} / \mathrm{m}^{3}$;

$c_{w}$ - ciepło właściwe wody, $\mathrm{kJ} /(\mathrm{kg} \cdot \mathrm{K})$;

$T_{p}$ - temperatura początkowa (na wyjściu ze skraplacza), ${ }^{\circ} \mathrm{C}$;

$T_{k}$ - temperatura końcowa (na wejściu ze skraplacza), ${ }^{\circ} \mathrm{C}$.

$\mathrm{Z}$ kolei strumień przepływu wody $V_{z}$ pobierany $\mathrm{z}$ niskotemperaturowego źródła ciepła obliczono z zależności (5) [10].

$$
V_{z}=\frac{Q_{c h}}{\rho_{w} \cdot c_{w} \cdot\left(T_{1}-T_{2}\right)}, \frac{m^{3}}{s}
$$

gdzie: $Q_{c h}-$ wydajność chłodnicza pompy ciepła, kW;

$\rho_{w}-$ gęstość wody, $\mathrm{kg} / \mathrm{m}^{3}$;

$c_{w}$ - ciepło właściwe wody, $\mathrm{kJ} /(\mathrm{kg} \cdot \mathrm{K})$;

$T_{1}$ - temperatura wody na wejściu do parownika, ${ }^{\circ} \mathrm{C}$;

$T_{2}$ - temperatura wody na wyjściu z parownika, ${ }^{\circ} \mathrm{C}$.

Pompę ciepła należy dobrać do wielkości strumienia ciepła doprowadzanego do pętli grzewczych ułożonych w warstwie sypkiej $Q$ oraz według wytycznych producenta. Dobór pozostałych elementów systemu ogrzewania płaszczyznowego (pomp obiegowych, zaworów odcinających, zaworów zwrotnych, filtrów, naczyń wzbiorczych oraz zaworów bezpieczeństwa) również prowadzi się w oparciu o wytyczne producentów [10]. 
Przykład obliczeniowy wykonano dla boiska piłkarskiego z nawierzchnią naturalną dokonując wstępnych założeń i bazując na danych wejściowych, którymi są:

- wymiary boiska: 30 x $62 \mathrm{~m}$ (pole gry 26 x $56 \mathrm{~m}$ ),

- temperatura powietrza atmosferycznego: $-8^{\circ} \mathrm{C}$,

- temperatura początkowa na wyjściu ze skraplacza $17^{\circ} \mathrm{C}$, a końcowa na wejściu do skraplacza $13^{\circ} \mathrm{C}$,

- temperatura początkowa na wejściu do parownika $6^{\circ} \mathrm{C}$, a końcowa na wyjściu z parownika $2^{\circ} \mathrm{C}$,

- temperatura gruntu: $10^{\circ} \mathrm{C}$,

- warstwa podkładu wymiennego: piasek o współczynniku przewodzenia ciepła $\lambda=1,2 \mathrm{~W} /\left(\mathrm{m}^{2} \cdot \mathrm{K}\right)$, na którym występuje nawierzchnia trawiasta; grubość warstwy $15 \mathrm{~cm}$.

- warstwa gruntu rodzimego: glina o współczynniku przewodzenia ciepła $\lambda=1,4 \mathrm{~W} /\left(\mathrm{m}^{2} \cdot \mathrm{K}\right)$, w której ułożono bezpośrednio rury grzewcze; grubość warstwy $10 \mathrm{~cm}$. beli 1 .

Wyniki obliczeń dla rozpatrywanego boiska sportowego zestawiono w ta-

$\mathrm{Na}$ podstawie danych $\mathrm{z}$ tabeli 1 oraz danych technicznych dostępnych w katalogach producentów dobrano przykładową pompę ciepła oraz przeciwprądowy wymiennik dostępne na rynku $[5,6]$ (tabela 1).

\section{Ocena efektywności finansowej inwestycji}

W przypadku instalacji z pompami ciepła i innych źródeł niekonwencjonalnych horyzont czasowy, w którym zauważa się korzyści ekonomiczne, jest stosunkowo długi, wobec tego uzasadnione jest stosowanie w obliczeniach metod dyskontowych [2].

W celu oceny efektywności finansowej zastosowania omówionego systemu ogrzewania płyty boiska sportowego przy użyciu pompy ciepła przeprowadzono analizę finansową zgodnie $\mathrm{z}$ metodą kosztów rocznych [7]. Metoda ta z założenia umożliwia obliczenie kosztów wytwarzania ciepła, w skład których wchodzą koszty bieżące (eksploatacyjne) oraz koszty pochodzące od zwrotu nakładów inwestycyjnych naliczane w przedziale czasowym jednego roku, który jest rokiem reprezentatywnym dla analizowanego horyzontu czasowego ekonomicznej eksploatacji obiektu - liczącego $N$ lat [3].

W tabeli 2 zamieszczono wyniki obliczeń kosztów poszczególnych elementów układu składających się na całkowite koszty inwestycyjne. Założono, że koszt pozostałych elementów dla instalacji wynosi $20 \%$ według propozycji [7]. Zgodnie z informacją uzyskaną od producentów pomp ciepła przyjęto koszt instalacji dolnego i górnego źródła ciepła na poziomie 30\% całkowitych nakładów inwestycyjnych. 
Tabela 1. Tabelaryczne zestawienie wyników obliczeń systemu ogrzewania powierzchniowego płyty boiska sportowego

Table 1. Summary calculation results for the hydronic turf heating system

\begin{tabular}{|c|c|}
\hline \multicolumn{2}{|c|}{$\begin{array}{c}\text { Zestawienie wyników obliczeń systemu ogrzewania powierzchniowego } \\
\text { płyty boiska sportowego }\end{array}$} \\
\hline Współczynnik przenikania ciepła $U_{b}, \mathrm{~W} / \mathrm{m}^{2} \cdot \mathrm{K}$ & 3,37 \\
\hline Powierzchnia płyty boiska $A, \mathrm{~m}^{2}$ & 1860 \\
\hline $\begin{array}{l}\text { Strumień ciepła doprowadzony do pętli grzew- } \\
\text { czych } Q, \mathrm{~kW}\end{array}$ & 112,94 \\
\hline Dobrana pompa ciepła & $\begin{array}{c}\text { Viessmann } \\
\text { Vitocal 300-W Pro, } \\
\text { Typ WW 301.A125 [6] }\end{array}$ \\
\hline Moc grzewcza dobranej pompy ciepła $Q_{p c}, \mathrm{~kW}$ & 113,0 \\
\hline Wydajność chłodnicza $Q_{\mathrm{d}}, \mathrm{kW}$ & 94 \\
\hline Pobór mocy elektrycznej $P, \mathrm{~kW}$ & 19 \\
\hline Stopień efektywności $\varphi,-$ & 5,9 \\
\hline Dobrany wymiennik ciepła & $\begin{array}{c}\text { Danfoss } \\
\text { HGF 100-050M-1-41 [5] }\end{array}$ \\
\hline Moc wymiennika $Q_{w}, \mathrm{~kW}$ & 111,98 \\
\hline $\begin{array}{l}\text { Temperatura na wlocie do wymiennika po } \\
\text { stronie wody grzewczej, }{ }^{\circ} \mathrm{C}\end{array}$ & 17 \\
\hline $\begin{array}{l}\text { Temperatura na wylocie z wymiennika po } \\
\text { stronie wody grzewczej, }{ }^{\circ} \mathrm{C}\end{array}$ & 13 \\
\hline $\begin{array}{l}\text { Temperatura na wlocie do wymiennika po } \\
\text { stronie glikolu etylenowego, }{ }^{\circ} \mathrm{C}\end{array}$ & 11 \\
\hline $\begin{array}{l}\text { Temperatura na wylocie } \mathrm{z} \text { wymiennika po } \\
\text { stronie glikolu etylenowego, }{ }^{\circ} \mathrm{C}\end{array}$ & 16 \\
\hline$L M T D, \mathrm{~K}$ & 1,44 \\
\hline Strumień przepływu wody grzewczej $V_{g}, \mathrm{~m}^{3} / \mathrm{s}$ & 0,0067 \\
\hline $\begin{array}{l}\text { Strumień przepływu wody pobierany } \\
\text { z niskotemperaturowego źródła ciepła } V_{z}, \mathrm{~m}^{3} / \mathrm{s}\end{array}$ & 0,0056 \\
\hline
\end{tabular}

Analizując dane z tabeli 2 można zauważyć, że nakłady inwestycyjne związane z zakupem samej pompy ciepła dużej mocy są bardzo wysokie i przewyższają koszty wykonania samej instalacji dolnego źródła ciepła oraz ogrzewania płaszczyznowego. 
Tabela 2. Nakład inwestycyjny na instalację pompy ciepła

Table 2. Cost of the heat pump installation

\begin{tabular}{|c|c|}
\hline \multicolumn{2}{|c|}{ Nakłady inwestycyjne na poszczególne elementy instalacji pompy ciepła } \\
\hline Pompa ciepła $K_{i p c}, \mathrm{zł}$ & 184149,96 \\
\hline Instalacja dolnego i górnego źródła ciepła $K_{\text {wym }}, \mathrm{zł}$ & 110489,98 \\
\hline $\begin{array}{c}\text { Pozostałe elementy instalacji: wymiennik ciepła, } \\
\text { rurociągi, armatura, układ automatyki oraz robocizna } \\
\text { i uruchomienie instalacji } K_{i p}, \mathrm{zł}\end{array}$ & 73659,98 \\
\hline Sumaryczny nakład inwestycyjny $K_{\text {inpc }}, \mathrm{zł}$ & 368299,92 \\
\hline
\end{tabular}

Założono, że analizowane boisko sportowe bedzie funkcjonowało w okresie od listopada do marca w godzinach od $8^{00}$ do $18^{00}$. Czas eksploatacji opisanego systemu, który odpowiada czasowi bezawaryjnej pracy sprężarek pomp ciepła, przyjęto na $N=20$ lat, zgodnie z zaleceniami producentów (wymiana informacji w rozmowach z przedstawicielami różnych przedsiębiorstw). Do obliczeń przyjęto aktualną cenę energii elektrycznej w taryfie G11, która w Rzeszowie wynosi $c_{e l}=0,59 \mathrm{zt} / \mathrm{kWh}$ [1]. Natomiast obliczenia wartości zaktualizowanej netto przedsięwzięcia przeprowadzono przy założeniu wartości stopy dyskontowej na poziomie $\mathrm{p}=8 \%$ zalecanej dla obiektów energetyki odnawialnej [7].

Charakterystycznymi składowymi metody kosztów rocznych są:

- rata zwrotu kapitałowego $r$,

- rata kosztów stałych $r+r_{c e}$,

- roczne koszty stałe $K_{r s t}$

- roczne koszty eksploatacyjne zmienne $K_{e z m}$,

- koszty roczne wytwarzania ciepła $K_{r p c}$,

- ilość ciepła użytecznego dostarczonego w ciągu roku przez pompę ciepła $Q_{a p c}$,

- jednostkowy koszt wytwarzanego ciepła $q_{p c}$. (6) [7].

Ratę zwrotu kapitałowego (rozszerzonej reprodukcji) $r$ obliczono ze wzoru

$$
r=\frac{p \cdot(1+p)^{N}}{(1+p)^{N}-1}
$$

gdzie: $p$ - stopa dyskontowa, \%;

$N$ - obliczeniowy okres eksploatacji obiektu, lata.

Ratę kosztów stałych $r+r_{c e}$ (suma raty rozszerzonej reprodukcji i raty kosztów eksploatacyjnych stałych) obliczono z zależności (7) [7].

$$
r+r_{c e}=0,12
$$


gdzie: $r_{c e}$ - stopa stałych kosztów eksploatacyjnych, \%; przyjęto $2 \%$ według propozycji [7]. (8) [7].

W celu obliczenia rocznych kosztów stałych $K_{r s t}$ posłużono się zależnością

$$
K_{r s t}=K_{r r}+K_{e s t}=K_{i n p c} \cdot r+K_{i n p c} \cdot r_{c e}=\left(r+r_{c e}\right) \cdot K_{\text {inpc }}
$$

gdzie: $K_{r r}$ - suma kosztów zwrotu kapitałowego, zł/rok;

$K_{\text {est }}$ - suma stałych kosztów eksploatacyjnych, zł/rok;

$K_{\text {inpc }}-$ całkowite nakłady inwestycyjne na instalację z pompą ciepła, zł.

Roczne koszty eksploatacyjne zmienne - składowa zmienna kosztów rocznych $K_{e z m}$ obliczono ze wzoru (9) [7].

$$
K_{e z m}=\frac{Q_{p c} \cdot T_{i p c} \cdot c_{e l} \cdot k_{m r}}{\varphi \cdot \eta_{s i l}}
$$

gdzie: $Q_{p c}-$ moc zainstalowana pompy ciepła, $\mathrm{kW}$;

$T_{i p c}$ - czas użytkowania mocy zainstalowanej pompy ciepła, $\mathrm{h} / \mathrm{rok}$;

$c_{e l}$ - cena energii elektrycznej, zł/kWh;

$k_{m r}$ - współczynnik kosztu materiałów ruchowych dla pompy ciepła, -; przyjęto 1,02 według propozycji [7];

$\varphi$ - średni roczny współczynnik wydajności grzejnej, -;

$\eta_{s i l}$ - sprawność silnika elektrycznego napędzającego sprężarkę pompy ciepła, wartość średnia roczna, \%; przyjęto 80\% według propozycji [7].

Koszty roczne wytwarzania ciepła $K_{r p c}$, jako suma składowej stałej i składowej zmiennej, obliczono z zależności (10) [7].

$$
K_{r p c}=K_{r s t}+K_{e z m}
$$

Ilość ciepła użytecznego dostarczanego w ciągu roku przez pompę ciepła obliczono ze wzoru (11) [7].

$$
Q_{a p c}=Q_{p c} \cdot T_{i p c}
$$

Jednostkowy koszt wytwarzanego ciepła $q_{p c}$ jest ilorazem kosztów rocznych i rocznie wytwarzanego ciepła użytecznego, można go określić w oparciu o wzór (12) [7].

$$
q_{p c}=\frac{K_{r p c}}{Q_{a p c}}
$$

Korzystając z zależności (13) obliczono zmniejszenie kosztów uzyskania ciepła $O$ na ogrzewanie płyty boiska sportowego za $1 \mathrm{kWh}$ w stosunku do kosztów energii elektrycznej [7]. 


$$
O=c_{e l}-q_{p c}
$$

Oszczędności uzyskane przez użytkownika w wyniku eksploatacji pompy ciepła w ciągu roku określono z zależności (14) [9].

$$
\Delta K=O-Q_{a p c}
$$

gdzie: $O$ - zmniejszenie kosztów uzyskania ciepła na ogrzewanie płyty boiska sportowego za $1 \mathrm{kWh}$ w stosunku do kosztów energii elektrycznej, $\mathrm{zt} / \mathrm{kWh}$,

$Q_{a p c}$ - ilość ciepła użytecznego dostarczona w ciągu roku przez pompę ciepła, $\mathrm{kWh} /$ rok.

Oznacza to, że prosty okres zwrotu nakładów $S P B T$ poniesionych na realizację inwestycji można obliczyć ze wzoru (15) [9].

$$
S P B T=\frac{K_{i n p c}}{\Delta K}
$$

Wyniki obliczeń przeprowadzonej oceny efektywności finansowej inwestycji zestawiono w tabeli 3 .

Analiza finansowa metodą kosztów rocznych wykazała, że ogrzewanie płyty boiska sportowego przy użyciu pompy ciepła jest bardziej opłacalne w odniesieniu do ogrzewania elektrycznego. Inwestycja nie tylko umożliwi zwrot nakładów początkowych, ale przyniesie dodatkowo zysk z uwzględnieniem zmiany wartości pieniądza w czasie. Jednostkowy koszt wytwarzanego ciepła $q_{p c}$ wynosi $0,22 \mathrm{zt} / \mathrm{kWh}$ i jest niższy od ceny $1 \mathrm{kWh}$ energii elektrycznej o $0,37 \mathrm{zł} / \mathrm{kWh}$. Obliczenia prostego okresu zwrotu nakładów inwestycyjnych $S P B T$ wykazały, że środki finansowe przewidziane na realizację inwestycji ulegną zwrotowi po niecałych 6 latach.

\section{Podsumowanie i wnioski}

Reasumując, można stwierdzić, że ogrzewanie płaszczyznowe znajduje zastosowanie nie tylko w budynkach mieszkalnych, ale jest również praktycznie jedynym rozwiązaniem dla otwartych przestrzeni, takich jak boiska. Wzrost cen energii wymusza na użytkownikach stosowanie instalacji i urządzeń grzewczych nowoczesnych, a jednocześnie ekonomicznych, wytwarzanych i eksploatowanych $w$ zgodzie $\mathrm{z}$ wymogami ochrony środowiska. Ogrzewanie murawy przy użyciu pompy ciepła pozwala na utrzymanie płyty boiska wolnej od śniegu i lodu. 
Tabela 3. Zestawienie wyników analizy finansowej

Table 3. Summary of the results of the financial analysis

\begin{tabular}{|c|c|}
\hline \multicolumn{2}{|c|}{ Wyniki oceny efektywności finansowej analizowanej inwestycji } \\
\hline Rata zwrotu kapitałowego $r$ & 0,10 \\
\hline Rata kosztów stałych $r+r_{c e}$ & 0,12 \\
\hline Roczne koszty stałe $K_{\text {rst }}$, zł/rok & 44878,16 \\
\hline $\begin{array}{c}\text { Roczne koszty eksploatacyjne zmienne } K_{e z m}, \\
\text { zł/rok }\end{array}$ & 21755,33 \\
\hline Roczne koszty wytwarzania ciepła $K_{r p c}$, zł/rok & 66633,48 \\
\hline Ilość ciepła użytecznego $Q_{a p c}, \mathrm{kWh/rok}$ & 170630 \\
\hline $\begin{array}{c}\text { Jednostkowy koszt wytwarzanego ciepła } q_{p c}, \\
\text { zł/kWh }\end{array}$ & 0,22 \\
\hline $\begin{array}{c}\text { Zmniejszenie kosztów uzyskania ciepła } O, \\
\text { zł/kWh }\end{array}$ & 0,37 \\
\hline $\begin{array}{c}\text { Oszczędności uzyskane przez użytkownika } \\
\text { w wyniku eksploatacji pompy ciepła } \Delta K, \text { zł/rok }\end{array}$ & 63525,50 \\
\hline \begin{tabular}{c}
$S P B T$, lata \\
\hline
\end{tabular}
\end{tabular}

Układ ten charakteryzuje się dużą efektywnością oraz niskimi kosztami eksploatacyjnymi. Znaczną wadą tego systemu jest duża korozyjność glikolu, co stwarza ryzyko powstawania wycieków sięgających niekiedy do kilkuset litrów na dobę.

Wykonana analiza finansowa wykazuje jednoznacznie, że ogrzewanie płyty boiska sportowego przy użyciu pompy ciepła jest technicznie możliwe, ale również opłacalne finansowo. Czas zwrotu inwestycji na instalację tego typu jest bardzo krótki, bowiem wynosi on mniej niż 6 lat. Wykazano, że jednostkowy koszt wytwarzanej przez pompę ciepła energii cieplnej $q_{p c}$ wynosi $0,22 \mathrm{zł} / \mathrm{kWh}$.

\section{Literatura}

[1] Ceny prądu w Polsce, http://zaklad.energetyczny.w.interia.pl. [dostęp: 3 stycznia 2016].

[2] Czarniecki D., Słyś D.: Analiza techniczna i finansowa odzysku ciepła odpadowego ze ścieków w miasteczku akademickim Politechniki Rzeszowskiej, Technologia Wody, nr 4, 2015, s. 73-81.

[3] Czarniecki D., Słyś D.: Analiza techniczna i finansowa wariantów ogrzewania wody z wykorzystaniem pomp ciepła współpracujących z systemami rozsączania wody deszczowej w produkcji roślinnej, Czasopismo Inżynierii Lądowej, Środowiska i Architektury, z. 61(3/I), 2014, s. 33-51. 
[4] Czarniecki D., Słyś D.: Wykorzystanie wód w instalacjach z pompami ciepła, [w:] Workshop o Vode, Harbulakova V., Zelenakova M., red., s. 10-24, Koszyce 2015.

[5] Katalog firmy Danfoss, http://danfoss.pl [dostęp: 3 stycznia 2016].

[6] Katalog firmy Viessmann, http://viessmann.pl [dostęp: 3 stycznia 2016].

[7] Kusto Z.: Uwarunkowania ekonomicznej efektywności pomp ciepła, IMP PAN, Gdańsk 2006.

[8] Niełacna D., Koczyk H.: Wpływ temperatury zewnętrznej oraz prędkości wiatru na rozkład temperatury w przekroju poprzecznym ogrzewanej murawy boiska sportowego, Ciepłownictwo, Ogrzewnictwo, Wentylacja, nr 3, 2007, s. 18-21.

[9] Onyszczuk G., Siuta-Olcha A.: Systemy ogrzewania otwartych przestrzeni na przykładzie projektu instalacji podgrzewanej murawy boiska sportowego, [w:] „Polska Inżynieria Środowiska pięć lat po wstąpieniu do Unii Europejskiej”, Tom 3, Dudzińska M.R., Pawłowski L., red., Monografie Komitetu Inżynierii Środowiska PAN, vol. 60, 2009.

[10] Pisarev V.: Projektowanie instalacji grzewczych z pompami ciepła, Oficyna Wydawnicza Politechniki Rzeszowskiej, Rzeszów 2013.

[11] Pochwat K.: Analysis of critical rainfall for dimensioning of sewage networks and storage reservoirs, IX Karpat-Medencei Kornyezettudomanyi Konferencia, 2013, s. 453-458.

[12] Rybka K.: Ogrzewana murawa - stadion zgodny z wymaganiami FIFA i UEFA, Rynek Instalacyjny, nr 1-2, 2014, s. 30-32.

[13] Słyś D., Kordana S.: Odzysk ciepła odpadowego w instalacjach i systemach kanalizacyjnych, Wydawnictwo i Handel Książkami „KaBe”, Krosno 2013.

[14] Słyś D.: Zrównoważone systemy odwodnienia miast, Dolnośląskie Wydawnictwo Edukacyjne, Wrocław 2013.

\title{
TECHNICAL AND FINANCIAL ANALYSIS OF HEATING TURF ON THE SPORTS FIELD
}

\begin{abstract}
S u m m a r y
In recent years, Poland has made up for the many years of backlog in the construction of sports infrastructure, dedicated primarily for children and young people and ensure that society wide and free access to modern sports facilities. Imperative need to seek new solutions, the use of which contribute to a significant improvement in terms of sports in the country. It is important to give priority to all ecological systems contributing to the rationalization of energy use and thereby also to protect air. The answer to this trend is heating sports fields and stadiums using a heat pump. The article presents the results of technical analysis surface heating the pitch by using this device as well as financial analysis of its use in the agreed conditions. Knowledge of these analyzes gives the opportunity to choose a preferred embodiment, the system for existing and newly built sports infrastructure, which can contribute significantly to the reduction of operating costs.
\end{abstract}

Keywords: sports field, turf heating installation, heat pump, renewable energy sources 
DOI: 10.7862/rb.2016.149

Przestano do redakcji: 01.05.2016 r.

Przyjęto do druku: 28.06.2016 r. 